\title{
KONSTRUKSI SOSIAL JANDA TEREKSPLOITASI (STUDI KASUS DI KELURAHAN TETEBATU KECAMATAN PALLANGGA KABUPATEN GOWA)
}

\section{CONSTRUCTION SOCIAL OF WIDOW'S EKSPLOITATION (A CASE STUDY AT TETEBATU VILLAGE, PALLANGGA, GOWA DISTRICT}

\author{
Andi Agustang \\ andi.agustang@unm.ac.id \\ Andi Irma Ariani \\ airmaariani@gmail.com \\ Andi Asrifan \\ andiasrifan@gmail.com
}

\section{Latar Belakang}

Sejak dahulu pernikahan usia dini sudah terjadi dari dahulu sampai sekarang, bahkan dari nenek-nenek moyang. Ini terjadi karena kurangnya pengetahuan warga setempat sehingga menyebabkan pernikahan usia dini. Remaja disana telah terdoktrin bahwa ketika memasuki umur 20 tahun keatas itu kemudian belum memutuskan untuk menikah adalah "perawan tua". Di kelurahan Tetebatu ada lorong yang lebih dikenal dengan sebutan "kampung janda" Mengapa ? karena di sana dominan terjadi perceraian pada usia muda, yang di nikahkan oleh orang tuanya dikarenakan masalah himpitan ekonomi seperti yang dapat menimbulkan konflik internal dalam keluarga, kekerasan dalam rumah tangga, tidak jelasnya sumber pendapatan (kerja), serta kebutuhan anak yang semakin hari semakin tinggi. Kemudian persoalan mendasar dari seorang anak perempuanya itu ketika memasuki usia dewasa, banyak orang tua menginginkan anaknya untuk tidak menjadi perawan tua, menjadi perawan tua bagi kebanyakan masyarakat dianggap sebagai bentuk kekurangan yang terjadi pada diri perempuan. Kondisi itulah yang menjadikan timbulnya persepsi bahwa remaja desa akan lebih dulu menikah daripada remaja kota. Anggapan tersebut muncul karena kurangnya pengetahuan dari masyarakat mengenai pentingnya pendidikan bagi remaja.

Di kampung janda disana, ada berbagai macam konflik yang terjadi sehingga berujung pada perceraian. Mayoritas mata pencaharian disana adalah petani, yang kemudian menggantungkan hidupnya dengan suami. Jadi ketika terjadi permasalahan, maka istri hanya bisa pasrah mengikuti apa yang di putuskan suami dan harus mengikuti setiap perkataannya. Seolah-olah menempatkan posisi pihak suami sebagai raja di lokasi 
tersebut. Persoalan inilah kemudian yang mengusik hati peneliti untuk meneliti lebih jauh mengenai hal ini, adanya berbagai macam sebab sehingga terjadi perceraian, salah satunya adalah tidak harmonisnya hubungan rumah tangga dan perempuan selalu di anggap salah. Ada sebagian dari mereka yang merasa bahwa hidup menjanda adalah hal biasa, bukan hal yang harus ditakutkan, atau dikucilkan. Bahkan ada yang bangga dengan kehidupan menjanda namun ada pula yang meratapi hidup menjandanya, yang membawa kesedihannya sampai anaknya berumur dewasa sehingga selalu menyalahkan dirinya sendiri, kemudian ada pula yang merasa risih akan status jandanya. Lantas kemudian mengapa bagi orang awam status janda itu adalah sebuah "aib". Pola pikir seperti inilah yang hendaknya di ubah, pada dasarnya janda adalah sebuah ketidaksempurnaan dalam berumah tangga. Akan tetapi kesempurnaan dalam berumah tangga bisa dibentuk kembali dengan pola pikir yang lebih positif kemudian di sertai dengan tindakan.

Jika seperti ini masalahnya, lantas kemudian mengapa selalu perempuan berada di posisi bawah dalam arti perempuan selalu di anggap lemah, tak berdaya, mudah menangis. Padahal perempuan juga sebenarnya menginginkan adanya kesetaraan gender, baik itu didalam pekerjaan, rumah tangga dan sebagainya. Walaupun pada dasarnya sosok laki-laki yang mendominasi di dalamnya karna adanya labeling sosok pemimpin dalam rumah tangga. Nah inilah kemudian semakin membuat peneliti merasa ingin menelitinya karna di satu sisi, pihak perempuan juga menginginkan adanya sebuah penghormatan, membutuhkan di hargai apalagi dengan suami sendiri, dan tidak menganggap bahwa perempuan selalu berada di posisi terendah yang lemah dan tidak bisa melalukan pekerjaan secara mandiri, di sisi lain ketika terjadi perpecahan di dalam rumah tangga, sosok perempuanlah yang selalu merasa tersudutkan, dan laki-lakilah yang selalu benar, apalagi jika hanya suami yang mempunyai wewenang tinggi dalam arti hanya suami yang bekerja dan istri hanya bekerja sebagai ibu rumah tangga, yang hanya bisa mengurus pekerjaan rumah sehingga seolah-olah terjadi eksploitasi. Lantas inilah kemudian yang semakin membuat suami memperlakukan istrinya dengan tidak sewajarnya, apalagi jika pernikahan tersebut sudah mulai goyah akan hadirnya pihak-pihak serta timbulnya masalah yang tidak di inginkan.

Ketika terjadi perceraian seperti ini, siapa yang akan di salahkan ? disatu sisi orang tua yang mengambil keputusan sepihak untuk menikahkan anaknya terlebih dahulu di usia belia, kemudian di sisi lain ada anak yang harusnya masih mendapatkan kasih sayang sepenuhnya oleh ayah dan ibunya tetapi telah bercerai. Tetapi, ada anak pula yang setelah terjadi perceraian orang tuanya, ia malah bangkit akan keterpurukan, ia berusaha untuk sukses untuk kehidupannya yang jauh lebih baik di kemudian hari. Anak seperti inilah yang kemudian akan membuktikan kesuksesannya 
kepada orang sekitar bahwa anak dari korban perceraian bisa pula menjadi orang besar.

Batas usia dalam melangsungkan pernikahan adalah sangat penting, karena hal ini menghendaki kematangan psikologis. Usia pernikahan yang terlalu muda dapat mengakibatkan meningkatnya kasus perceraian dan kekerasan, karena kurangnya kesadaran untuk bertanggung jawab dalam kehidupan berumah tangga. Pernikahan yang sukses sering ditandai dengan kesiapan memikul tanggung jawab. Begitu memutuskan untuk menikah, mereka siap menanggung segala beban yang timbul akibat pernikahan, baik yang menyangkut pemberian nafkah, pendidikan anak, maupun yang berkaitan dengan perlindungan, serta pergaulan yang baik. Tujuan dari pernikahan yang lain adalah memperoleh keturunan yang baik. Dengan pernikahan pada usia yang terlalu muda, sangat sulit memperoleh keturunan yang berkualitas. Kedewasaan ibu juga sangat berpengaruh terhadap perkembangan anak, karena ibu yang telah dewasa secara psikologis akan lebih terkendali emosi maupun tindakannya bila dibandingkan dengan para ibu muda.

\section{Rumusan Masalah}

Bertitik tolak pada latar belakang masalah, maka dapat dirumuskan masalah penelitian sebagai berikut:

1. Apa penyebab terjadinya konstruksi sosial janda tereksploitasi di Kelurahan Tetebatu Kecamatan Pallangga Kabupaten Gowa?

2. Bagaimana dampak konstruksi sosial janda tereksploitasi di Kelurahan Tetebatu Kecamatan Pallangga Kabupaten Gowa?

\section{TINJAUAN PUSTAKA}

\section{Pernikahan Usaha Dini}

Menikah, berkeluarga adalah untuk menyambung tali-tali yang menguatkan satu sama lain dalam kehidupan di dunia ini, sehingga setiap upaya dan ikhtiar hendaknya dapat memperkokoh bangunan keluarga itu, seperti: keseimbangan antara hak dan kewajiban, kesetiaan, ketulusan, keikhlasan, dan saling melengkapi antara suami, istri, orang tua (mertua), dan juga anak-anaknya (Gus, 2016: 13).

Ilham (2017) Pernikahan usia anak atau lebih di kenal dengan istilah pernikahan dibawah umur merupakan salah satu fenomena sosial yang banyak terjadi di berbagai tempat di tanah air, baik di perkotaan maupun di pedesaan. Baik kalangan menengah ke atas maupun menengah ke bawah. Di daerah perkotaan sebanyak $21,75 \%$ anak-anak di bawah usia 16 tahun sudah di nikahkan. Di pedesaan, angkanya jauh lebih besar yaitu $47,79 \%$ yang menampakkan kesederhanaan pola pikir masyarakatnya sehingga mengabaikan banyak aspek yang seharusnya menjadi syarat dari suatu perkawinan. Pernikahan usia dini akan berdampak pada kualitas anak, keluarga, keharmonisan keluarga dan perceraian karena pada masa tersebut, ego remaja masih tinggi. Tetapi, perlu di ketahui 
bahwa ketika orang tua memutuskan untuk menikahkan anaknya di usia belia, kita harus paham apakah himpitan ekonomi dari segi jenis ada lilitan utang di dalamnya, ataukah ingin bebas atau angkat tangan dalam membiayai anak tersebut, ataukah anak tersebut anak yatim sehingga di nikahkan dini oleh orang tuanya. Hal inilah yang semakin membuat peneliti untuk mengkajinya lebih jauh dengan terjun ke lapangan untuk melakukan sebuah penelitian, karena beda atap beda masalah. Artinya tidak semua masalah rumah tangga itu sama.

Selain aspek fisik, umur ibu juga mempengaruhi aspek psikologi anak. Seorang ibu yang masih berusia remaja sebenarnya belum siap untuk menjadi ibu dalam arti keterampilan mengasuh anaknya. Ibu muda lebih menonjolkan sifat keremajaannya daripada sifat keibuannya. Sifat-sifat keremajaan ini seperti, emosi yang tidak stabil, belum mempunyai kemampuan yang matang untuk menyelesaikan konflik-konflik yang dihadapi, serta belum mempunyai pemikiran yang matang tentang masa depan yang baik akan sangat mempengaruhi perkembangan psikososial anak.

Rani (2015) Faktor rendahnya tingkat ekonomi pernikahan usia dini yang terjadi di dalam masyarakat, hal ini berhubungan dengan rendahnya tingkat ekonomi masyarakat. Orang tua tidak memiliki kemampuan untuk memenuhi kebutuhan keluarga sehingga orang tua memilih untuk mempercepat pernikahan anaknya, terlebih lagi anak perempuan sehingga dapat mengurangi pemenuhan kebutuhan keluarga. Faktor lainnya yang fenomenal adalah kasus-kasus hamil di luar nikah, kasus ini sudah parah dan sulit untuk di obati karna itu yang perlu di pikirkan adalah calon bayi yang di kandung agar ketika lahir sudah melihat kedua orang tuanya memiliki pernikahan yang sah di mata undang-undang. Hal ini menunjukkan bahwa penegakan hukum di Indonesia masih sangat lemah dan tidak memperdulikan UU Perkawinan, UU Perlindungan Anak serta UU Kekerasan Dalam Rumah Tangga yang telah di sahkan oleh pemerintah Republik Indonesia.

Trisna, Mayasari (2015) Melihat begitu banyak dampak negatif pernikahan dini akan tetapi pernikahan usia dini juga memilki dampak positif yakni: memperjelas status perkawinan, mendapat pengakuan yang baik dari lingkungan dan menjaga diri dari perbuatan zina yang tidak terkendali.

\section{Perceraian}

Konflik dalam perkawinan yang dapat menyebabkan keretakan hubungan suamiisteri atau bahkan dapat juga menyebabkan perceraian, biasanya bersumberkan pada kepribadian suami-isteri dan hal-hal yang erat kaitannya dengan perkawinan. Konflik yang bersumberkan pada kepribadian pada umumnya disebabkan oleh ketidakmatangan kepribadian, adanya sifat-sifat kepribadian yang tidak cocok untuk menjalin hubungan perkawinan, dan adanya kelainan mental. Sedangkan konflik-konflik yang bersumberkan pada hal-hal yang erat kaitannya dengan perkawinan, biasanya disebabkan oleh adanya perbedaan sikap dan pandangan suami-isteri dalam hal-hal tertentu. Dalam kasus cinta buta, orang tanpa sadar telah di eksploitasi atas nama cinta. Orang akan memberikan apa saja demi cinta, yang dalam bahasa kerennya adalah "pengorbanan cinta" (Syukurman, 2019: 50). 
Perceraian biasanya berawal dari suatu konflik, yang tidak menemukan benang merahnya. Memang biasanya masing-masing pihak mencari jalan keluar dan berusaha buntu, dan jika situasi ini terjadi maka suasana rumah pun akan menjadi lain, sehingga perceraian tidak bisa terelakkan, terhadap berbagai penelitian dan pengalaman empirik, perceraian ini dapat disebabkan oleh berbagai faktor, seperti faktor ekonomi, perbedaan usia yang cukup besar, keinginan untuk memperoleh anak, dan prinsip hidup yang berbeda sehingga tidak ada kecocokan lagi, ada juga yang disebabkan perselingkuhan diantara satu pasangan, serta ada pula yang tidak mau dimadu oleh suaminya, dan sudah tidak adanya komitmen untuk melanjutkan rumah tangganya (Ulfiah, 2016: 121).

Perceraian itu tidak hanya menyakitkan, menyedihkan tetapi juga membawa dampak sosial yang tidak kecil terutama bagi pasangan yang sudah memiliki keturunan. Oleh karena itu, sedapat mungkin dicari jalan yang lain (selain jalan perceraian). Namun apabila tidak ada jalan, maka jalan inilah yang harus diambil.

Nur (2016) Metode Terapi Agama Bagi Pasangan Pernikahan Usia Dini di Desa Bontosunggu Kecamatan Bontonompo Selatan Kabupaten Gowa menjelaskan tentang dampak pernikahan usia dini terhadap rumah tangga pasangan itu sendiri dan anaknya dan metode terapi agama yang tepat diberikan kepada pasangan pernikahan sesuai kondisinya.

Nurul (2016) Dampak Sosial Pernikahan Dini di Kelurahan Samalewa Kecamatan Bungoro Kabupaten Pangkajene dan Kepulauan. Membahas tentang faktor-faktor apa yang menyebabkan pernikahan usia dini, dan dampak sosial yang terjadi akibat pernikahan usia dini.

Jumardin (2016) Pengaruh Perkawinan di Bawah Umur Terhadap Tingkat Perceraian Pengadilan Agama Kelas 1 B Sengkang (Studi Kasus Tahun 20142016) membahas tentang faktor-faktor pendorong terjadinya pernikahan dini, dan pengaruh dari adanya perkawinan di bawah umur terhadap tingkat perceraian di pengadilan agama kelas $1 \mathrm{~B}$ memiliki pengaruh terhadap Nur Rakhmi Said. "Metode Terapi Agama Bagi Pasangan Pernikahan Usia Dini di Desa Bontosunggu Kecamatan Bontonompo Selatan Kabupaten Gowa" Skripsi S1 Fakultas Dakwah dan Komunikasi, Universitas Islam Negeri Alauddin Makassar, 2016. Nurul Izzah. "Dampak Sosial Pernikahan Dini di Kelurahan Samalewa Kecamatan Bungoro Kabupaten Pangkajene dan Kepulauan" Skripsi S1 Fakultas Dakwah dan Komunikasi, Universitas Islam Negeri Alauddin Makassar, 2016 tingkat perceraian karena perkawinan di bawah umur merupakan salah satu faktor pendorong terjadinya perceraian.

Dari beberapa penelitian di atas pada hakikatnya pembahasan tentang pernikahan dini sudah ada, pada skripsi pertama membahas tentang metode terapi agama terhadap pasangan pernikahan usia dini, serta efeknya terhadap ibu dan anak dan keharmonisan dalam keluarga itu. Skripsi kedua membahas tentang faktor-faktor penyebab pernikahan dini, dan dampak dari adanya pernikahan dini. Dan skripsi 
ketiga membahas tentang Faktor pendorong perkawinan dibawah umur pengadilan agama kelas 1 B Sengkang. Sedangkan disertasi peneliti membahas tentang pengaruh pernikahan dini terhadap peningkatan angka perceraian.

Dari penjelasan pernikahan di atas, dapat disimpulkan bahwa kedewasaan ibu baik secara fisik maupun mental sangat penting, karena hal itu akan berpengaruh terhadap perkembangan anak kelak dikemudian hari. Oleh sebab itulah maka sangat penting untuk memperhatikan umur pada anak yang akan menikah. Meskipun batas umur pernikahan telah ditetapkan dalam pasal 7 ayat (1) Undangundang No. 1 Tahun 1974, yaitu pernikahan hanya diizinkan jika laki-laki sudah mencapai umur 19 tahun dan pihak perempuan sudah mencapai umur 16 tahun, namun dalam praktiknya masih banyak dijumpai pernikahan usia muda atau di bawah umur. Padahal pernikahan yang sukses membutuhkan kedewasaan tanggung jawab secara fisik maupun mental, untuk bisa mewujudkan harapan yang ideal dalam kehidupan berumah tangga.

Terkadang masalah ekonomi merupakan faktor yang sangat rentan dalam menimbulkan problem rumah tangga, baik masalah ekonomi yang cukup bahkan berlebih hingga masalah ekonomi yang kurang bahkan sangat berkekurangan ataupun masalah dalam pengaturan keuangan keluarga. Mereka yang memiliki penghasilan cukup dan hidup dalam kemapanan juga tak lepas dari masalah perekonomian seperti, hutang-piutang, obsesi ingin semakin kaya sekalipun dengan cara yang haram, gaya hidup mewah, perebutan warisan dan sebagainya. Rizkillah (2015) keadaan keuangan atau pendapatan salah satu yang mempengaruhi kepuasan pernikahan. Tekanan ekonomi yang disebabkan pengeluaran yang lebih besar dari penghasilan dan hutang, tingginya tekanan ekonomi ini dapat menyebabkan kehidupan keluarga tidak membahagiakan lagi.

Manusia modern sibuk mencari apa yang mereka cintai. Cinta bukan tentang siapa yang kita cintai, tetapi cara kita mencintai. Problem cinta manusia modern adalah ketidakmengertian mereka tentang cara (seni) mereka mencintai. Kondisi demikian menyebabkan orag tidak bisa membedakan cinta dan perasaan egois. Cinta itu tidak menyakiti, tetapi ia memberi warna buah hidupmu (Erich, 2018: 22).

Setiap tahapan perkembangan keluarga mempunyai tugas krisis yang berbedabeda. Pelaksanaan tugas krisis ini akan berhubungan dengan kepuasan pernikahan. Faktor pendidikan juga dapat berhubungan dengan pengetahuan orang tua dalam melaksanakan tugas perkembangan keluarga. Penelitian sebelumnya Rahmaita (2015) mengkaji tugas perkembangan dan kepuasan pernikahan pada keluarga dengan anak pertama bayi, sedangkan pada penelitian lebih mengaji keluarga utuh yang menikah muda dengan memiliki anak pertama usia prasekolah (2,5-5 tahun). Apabila keluarga dapat melaksanakan tugas perkembangan keluarga dengan baik, maka kepuasan pernikahan akan tercapai secara optimal. 
Menurut UU No.1 Tahun 1974, pernikahan adalah ikatan lahir batin antara seorang laki-laki dan perempuan sebagai suami-istri dengan tujuan membentuk keluarga, rumah tangga yang bahagia dan kekal berdasarkan Ketuhanan Yang Maha Esa. Sedangkan menurut pandangan islam, pernikahan adalah suatu bentuk ibadah dimana seorang laki-laki dan perempuan melakukan akad dengan tujuan meraih kehidupan yang sakinah (tenang, damai), mawaddah (saling mencintai dan penuh kasih sayang), serta warahmah (kehidupan yang dirahmati Allah).

Didalam masyarakat, kasus perceraian sering dianggap suatu peristiwa menegangkan dalam kehidupan keluarga dan senantiasa membawa dampak yang mendalam. Kasus ini menimbulkan stress, tekanan dan menimbulkan perubahan fisik, dan mental. Kasus perceraian ada pula yang membawa kebahagiaan batin kepada masing-masing pasangan namun itu terjadi pada perasaan orang tua saja bukan mempertimbangkan apa yang akan terjadi pada perasaan anak yang tercermin pada perilaku anak kelak.

\section{Kekerasan dalam eksploitasi Perempuan}

Akhir-akhir ini kekerasan dalam rumah tangga menjadi topik utama pemberitaan media massa. Perempuan dalam kasus tersebut seakan menjadi pihak yang tereksploitasi, lemah, termarjinalkan, bahkan teraniaya. Tak jarang pula pemberitaan disajikan dengan begitu gamblang oleh media massa hingga makin memojokkan posisi perempuan dan kini fenomena yang terjadi berada di Kabupaten Gowa, khususnya di kelurahan Tetebatu Kecamatan Pallangga.

Dalam Women's Studies Encyclopedia, gender adalah suatu konsep kultural yang berupaya membuat pembedaan (distinction) dalam hal peran, perilaku, mentalitas, dan karakteristik emosional antara laki-laki dan perempuan yang berkembang dalam masyarakat. Berbeda dengan sex (jenis kelamin) yang dapat dilihat sebagai kodrat (tidak dapat diubah, diganti, ditukar), gender adalah hasil dari dari konstruksi budaya masyarakat. Sayangnya, di kotomi selalu menciptakan adanya dominasi. Dalam hal ini, kondisi budaya dan sosial masyarakat Indonesia yang menjunjung sistem patriarki menempatkan posisi perempuan di bawah laki-laki. Janda cantikterasa lebih menarik dan "menjual" dibanding jika ditulis janda atau perempuan tanpa suami saja. Eksploitasi semakin menjadi ketika menyetubuhi bahkan menghamili perempuan dianggap sebagai sebuah prestasi dan pencapaian (berhasil menghamili).

(Burhan, 2017: 193) Istilah konstruksi sosial atas realitas (social construction of reality), menjadi terkenal sejak di perkenalkan oleh Peter L. Berger dan Thomas Luckmann melalui bukunya yang berjudul "The Social Construction of Reality, a treatise in the sociological of knowledge" (1966). Ia menggambarkan proses sosial melalui tindakan dan interaksinya, yang mana individu menciptakan secara terus-menerus suatu realitas yang di miliki dan di alami bersama secara subjektif.

Keindahan perempuan menempatkan perempuan dalam stereotip perempuan dan membawa mereka ke sifat-sifat di sekitar keindahan itu, seperti perempuan harus 
tampil menawan, pandai mengurus rumah tangga, memasak, tampil prima untuk menyenangkan suami dan pantas di ajak ke berbagai acara, cerdas serta sumber pengetahuan dan moral keluarga. Stereotip ini menjadi ide dan citra sekaligus sumber eksploitasi perempuan di berbagai media, juga menjadi sumber protes terhadap iklan-iklan yang di anggap "melecehkan" citra itu. Gagasan ini di perkuat oleh (Walby 2014: 28) yang menyatakan bahwa patriarki adalah "sebuah sistem struktur sosial dan praktik-praktik dimana laki-laki mendominasi, menindas, dan mengeksploitasi perempuan". Penderitaan yang berseumber dari unsur "rasa" yang ada dalam diri manusia adalah ungkapan perasaan sakit yang di alami manusia dalam kehidupan (Sri, 2016: 277). Kehidupan keluarga yang memuat nilai-nilai patriarki menentukan sikap dan peran yang di lakukan oleh setiap kepala dan anggota keluarga. Prinsip-prinsip dominan terus berlangsung dalam tatanan sosial pada jangka waktu yang sangat lama, sehingga membuat anak perempuan menganggap normal, bahkan natural, tatanan sosial itu sebagaimana adanya dan membuat mereka menetukan takdir berdasarkan tatanan tersebut. Demikian juga laki-laki menilai semua yang berlaku dalam tatanan sosial sebagai suatu yang normal terutama posisi laki-laki sebagai pimpinan memiliki hak mengatur, mengontrol, dan menentukan nilai-nilai yang berlaku. Peran lakilaki di ranah publik mengikuti kegiatan sosial dan organisasi kemasyarakatan di nilai sebagai peran dan pekerjaan utama (Muhammad, 2018: 94).

Pertanggungjawaban hukum pelaku yakni sesuai dengan pasal yang telah di atur dalam UU Penghapusan Kekerasan Dalam Rumah Tangga (PKDRT), karna dalam pasal 5 di atur setiap orang dilarang melakukan kekerasan dalam rumah tangga terhadap orang dalam ruang lingkup rumah tangganya, dengan cara kekerasan fisik, kekerasan psikis, kekerasan seksual atau pelantaran rumah tangga. Pasal yang di gunakan untuk pertanggungjawaban hukum pelaku adalah pasal yang berkaitan dengan kekerasan fisik, seksual, psikis, dan pelataran. Kekerasan mana yang di lakukan oleh pelaku maka sesuai pasal yang berkaitan yang akan di mintai pertanggungjawaban pelaku. Berikut pasal-pasal terkait: dalam UU No.23 tahun 2004 bab VIII terkait ketentuan pidana, ada 5 pasal yang dapat di kaitkan dengan pertanggungjawaban hukum oleh apa yang telah di lakukan pelaku, yakni: (1) pasal 44 mengatur tentang a. ayat (1) setiap orang yang melakukan kekerasan fisik dalam ruang lingkup rumah tangga sebagaimana di maksud dalam pasal 5 huruf a, di pidana dengan pidana penjara paling lama 5 (lima) tahun atau dengan denda paling bayak Rp. 15.000.000,00 (Mahrus, 2015:156).

\section{METODE PENELITIAN}

\section{Jenis Penelitian}

Penelitian ini menggunakan jenis penelitian kualitatif tipe deskriptif, yang dimana data yang dikumpulkan lebih mengambil bentuk kata-kata atau gambar dari pada angka-angka sebagai alat metode utamanya.Bogdan dan Taylor dalam (Moleong, 2007:4) mendefinisikan metodologi kualitatif sebagai prosedur penelitian yang menghasilkan data deskriptif berupa kata-kata tertulis atau lisan dari orang-orang 
dan perilaku yang dapat diamati.Menurut mereka, pendekatan ini diarahkan pada latar dan individu tersebut secara holistik (utuh).

\section{Lokasi Penelitian}

Penelitian ini dilaksanakan di Kelurahan Tetebatu Kecamatan Pallangga Kabupaten Gowa tentang konstruksi sosial janda tereksploitasi. Alasan pemilihan lokasi penelitian di Kelurahan Tetebatu Kecamatan Pallangga Kabupaten Gowa karena melihat fenomena ada yang unik didaerah Tetebatu, masyarakat menyebutnya "kampung janda" sehingga peneliti tertarik untuk menelitinya lebih jauh.

\section{Pendekatan Studi Kasus}

Studi Kasus di Kelurahan Tetebatu Kecamatan Pallangga Kabupaten Gowa.Pendekatan studi kasus adalah sebuah studi kasus yang dikumpulkan berasal dari berbagai sumber dan hasil penelitian dan hanya berlaku pada kasus yang diselidiki. Penelitian studi kasus akan kurang kedalamannya bilamana hanya dipusatkan pada fase tertentu saja atau salah satu aspek tertentu sebelum memperoleh gambaran umum tentang kasus tersebut. Sebaliknya studi kasus akan kehilangan artinya kalau hanya ditujukan sekedar untuk memperoleh gambaran umum namun tanpa menemukan sesuatu atau beberapa aspek khusus yang perlu dipelajari secara intnensif dan mendalam.

Disamping itu, studi kasus yang baik harus dilakukan secara langsung dalam kehidupan sebenarnya dari kasus yang diselidiki. Walaupun demikian, data studi kasus dapat diperoleh tidak saja dari kasus yang diteliti, tetapi juga dapat diperoleh dari semua pihak yang mengetahui dan mengenal kasus tersebut dengan baik. Dengan kata lain, data dalam studi kasus dapat diperoleh dari berbagai sumber namun terbatas dalam kasus yang akan diteliti tersebut.

Penelitian case study atau penelitian lapangan (field Study) dimaksudkan untuk mempelajari secara intensif tentang latar belakang masalah keadaan dan posisi suatu peristiwa yang sedang berlangsung saat ini, serta interaksi lingkungan unit social tertentu yang bersifat apa adanya (given). Subjek penelitian dapat berupa individu, kelompok, institusi atau masyrakat.Penelitian case study merupakan studi mendalam mengenai unit sosial tertentu dan hasil penelitian tersebut memberikan gambaran luas serta mendalam mengenai unit sosial tertentu.Subjek yang diteliti relative terbatas, namun variabel-variabel dan fokus yang diteliti sangat luas dimensinya (Danim, 2002).

\section{Target/Informan Penelitian}

Penentuan target/informan pada penelitian ini menggunakan Teknik Purposive Sampling. Teknik purposive sampling adalah teknik penentuan sampel dengan pertimbangan tertentu, dimana peneliti cenderung memilih responden secara variatif berdasarkan (alasan). Dalam pemilihan ini peneliti akan sampel dari masing-masing usia untuk melihat pernikahan usia dini. 


\section{Data, Intrumen, dan Teknik Pengumpulan Data}

Penelitian ini menggunakan sumber data secara tertulis dan lisan.Teknik pengumpulan data yang pertama observasi yang meliputi pedoman observasi, pedoman wawancara, dan telaah dokumen.Pertama, pengamatan dan pencatatan yang sistematis terhadap gejala-gejala yang diteliti. Observasi menjadi salah satu teknik pengumpulan data apabila sesuai dengan tujuan penelitian, direncanakan, dan dicatat secara sistematis, serta dapat dikontrol keandalan reliabilitas dan kesahihannya atau validitasnya. Usman, (2011: 51).

Kedua, suatu bentuk komunikasi verbal semacam percakapan yang bertujuan memperoleh informasi mengenai topik penelitian. Proses wawancara dapat dilakukan oleh kedua belah pihak yakni pewawancara dan diwawancara. Menurut James dan Dean dalam Paizaluddin, (2013:130) wawancara adalah suatu kegiatan komunikasi verbal dengan tujuan mendapatkan informasi disamping mendapatkan gambaran yang menyeluruh, juga akan mendapatkan informasi yang penting. Dalam proses wawancara ada beberapa bentuk-bentuk pertanyaan yang akan diajukan oleh pewawancara yakni : wawancara tidak terstruktur atau terbuka dan wawancara terstruktur. Wawancara terstruktur yaitu wawancara dengan mengajukan pertanyaan yang menuntut jawaban-jawaban tertentu.Misalnya setuju, ragu-ragu, tidak setuju. Sedangkan wawancara tidak terstruktur yaitu wawancara yang dilakukan peneliti dengan mengajukan pertanyaan-pertayaan yang tidak dibatasi jawabannya, artinya pertanyaan yang mengundang jawaban yang terbuka.

Ketiga, Dokumentasi adalah sekumpulan berkas dengan mencari data mengenai hal-hal berupa catatan, transkrip, buku, surat kabar, majalah, prasasti, agenda dan sebagainya. Yuwono, (1994: 125). Studi dokumen merupakan teknik pengumpulan data yang tidak ditujukan langsung kepada subjek penelitian.Tujuan digunakan metode ini untuk memperoleh data secara jelas dan konkret tentang gambaran lokasi yang berkaitan dengan topik penelitian. Menurut Riyanto, (1996:84) bahwa dokumentasi berasal dari kata dokumen, yang artinya barang barang tertulis, dokumentasi juga bisa berarti cara mengumpulkan data dengan mencatat data data yang sudah ada.

\section{Teknik Pengabsahan Data}

Pengabsahan data atau validitas data ini diterapkan dalam rangka membuktikan kebenaran temuan hasil penelitian dengan kenyataan dilapangan.Teknik pengabsahan data yang digunakan untuk menguji kredibilitas data dalam penelitian ini adalah member check. Sugiyono, (2014: 276) Member check merupakan proses pengecekan data yang berasal dari pemberi data dengan tujuan untuk mengetahui seberapa jauh data yang diperoleh sesuai dengan apa yang diberikan oleh pemberi data dan dilakukan untuk mengambil temuan kembali pada partisipan dan menanyakan pada mereka baik lisan maupun tertulis tentang keakuratan hasil penelitian. 


\section{Teknik Analisis Data}

Data yang diperoleh dilapangan kemudian diolah secara deskriptif kualitatif dengan melalui tiga tahap yaitu reduksi data, penyajian data dan penarikan kesimpulan.

1. Reduksi Data,data yang diperoleh dilapangan yang ditulis atau diketik dalam bentuk uraian atau laporan yang terperinci. Laporan ini akan terus menerus bertambah dan akan menambah kesulitan bilamana tidak dianalisis sejak awal. Laporan-laporan itu perlu direduksi, dirangkum, dipilih hal-hal yang pokok difokuskan pada hal-hal yang penting, dicari tema atau polanya.Jadi laporan lapangan menjadi menjadi bahan mentah, disingkatkan direduksi, disusun lebih sistematis, sehingga lebih mudah dikendalikan.Data yang direduksi memberi gambaran yang lebih tajam tentang hasil pengamatan, juga mempermudah penelitian untuk mencari kembali data yang diperoleh bila diperlukan.

2. Penyajian Data, langkah kedua dari analisis data yakni penyajian data yaitu suatu kumpulan informasi yang tersusun yang membolehkan pendeskripsian kesimpulan dan pengambilan tindakan.

3. Penarikan Kesimpulan, langkah ketiga aktivitas analisis data adalah penarikan dan verifikasi kesimpulan. Dari permulaan pengumpulan data peneliti kualitatif mulai memutuskan apakah makna sesuatu, mencatat keteraturan, pola-pola, penjelasan, kemudian akan meningkat menjadi eksplisit dan mendasar sehingga menjadi suatu kesimpulan yang bersifat induktif.

\section{DAFTAR PUSTAKA}

Ali, Mahrus. 2015. Dasar-Dasar Hukum Pidana. Jakarta Timur: Sinar Grafika. Arifin, Gus. 2016. Menikah Untuk Bahagia. Jakarta: Elex Media Komputindo. Ariska, Ayu. (2017). Metode Dakwah dalam Menanggulangi Pernikahan Usia Dini di Desa Gunung Perak Kecamatan Sinjai Barat Kabupaten Sinjai. Undergraduate (S1) thesis, Universitas Islam Negeri Alauddin Makassar. Di akses 15 Desember 2019.

Bawa Nengah, 2018. Sosiologi Media Perspektif Teori Kritis. Depok: Grafindo.

Bungin, Burhan, 2017. Sosiologi Komunikasi Teori, Paradigma, dan Diskursus Teknologi Komunikasi di Masyarakat. Jakarta: Kencana.

Farid, Muhammad. 2018. Fenomenologi Dalam Penelitian Ilmu Sosial. Jakarta: Prenadamedia Group.

Fitriyaningsih, Rani.( 2015). Faktor-faktor penyebab pernikahan usia muda perempuan desa sumberdanti kecamatan sukowono kabupaten jember. Jember: Pendidikan Ekonomi Universitas Jember. Diakses 14 Desember 2019

Fromm, Erich. 2018. Seni Mencintai. Yogyakarta: Basa Basi.

Izzah, Nurul. (2016). Dampak Sosial Pernikahan Dini di Kelurahan Samalewa Kecamatan Bungoro Kabupaten Pangkajene dan Kepulauan. Skripsi S1 
Fakultas Dakwah dan Komunikasi, Universitas Islam Negeri Alauddin Makassar. Di akses 15 Desember 2019.

Jumardin, (2016). Pengaruh Perkawinan di Bawah Umur Terhadap Tingkat Perceraian Pengadilan Agama Kelas 1 B Sengkang (Studi Kasus Tahun 2014-2016). Skripsi S1 Fakultas Syariah dan Hukum. Universitas Islam Negeri Alauddin Makassar. Di akses 15 Desember 2019.

Laman, Ilham. (2017). Perkawinan di Bawah Umur di Kelurahan Purangi

Kota Palopo. Universitas Negeri Makassar, Makassar, Indonesia. Diakses 15 Desember 2019.

Mayasari, Trisna. (2015). Pengaruh Perkawinan Di Bawah Umur Terhadap Tingkat Perceraian (Studi Kasus di Kecamatan Mariso Dan Pengadilan Agama Kora Makassar. S1 Fakultas Syariah Dan Hukum Uin Alauddin Makassar.

Moleong, J.Lexy. 2007. Metodologi Penelitian Kualitatif. Bandung: Rosdakarya. Paizaluddin. 2013. Penelitian Tindakan Kelas Panduan Teoritis dan Praktis. Bandung: Alfabeta.

Rahaju, Sri. 2016. Ilmu Sosial Budaya Dasar. Yogyakarta: Andi Offset.

Rahmaita. (2015). Pengaruh tugas perkembangan keluarga dan stres ibu yang baru memiliki anak pertama terhadap kepuasan pernikahan. Institut Pertanian Bogor, Bogor, Indonesia. Diakses 14 Desember 2019.

Rakhmi, Nur Said. (2016). Metode Terapi Agama Bagi Pasangan Pernikahan Usia Dini di Desa Bontosunggu Kecamatan BontonompoSelatan

Kabupaten Gowa. Skripsi S1 Fakultas Dakwah dan Komunikasi, Universitas Islam Negeri Alauddin Makassar. Di akses 15 Desember 2019.

Rizkillah R., Sunarti E., \& Herawati T. (2015). Kualitas pernikahan dan lingkungan pengasuhan pada keluarga dengan suami istri bekerja. Jurnal Ilmu Keluarga dan Konsumen, 8(1), 10-19. doi: http://dx.doi.org/10.24156/jikk.2015.8.1.1 0. Diakses 11 Desember 2019

Sugiyono, 2014. Metode Penelitian Kuantitatif Kualitatif dan R \& D. Jakarta:

Alfabeta.

Sugiyono, 2015. Metode Penelitian Pendidikan: Kuantitatif, Kualitatif, dan

R\&D. Bandung: Alfabeta.

2019. Metode Penelitian Kuantitatif Kualitatif dan R\&D.

Bandung: Alfabeta

Syukurman, 2019. Sosiologi Cinta. Yogyakarta: Elmatera.

Usman, 2011. Metode Penelitian Sosial. Jakarta: Bumi Aksara.

Walby, Sylvia. 2014. Teorisasi Patriarki. Yogyakarta: Jalasutra.

\section{Rujukan Inspirasi}

Ma'na, P., Agustang, A., Salusu, J., Ikhsan, A., \& Dirawan, G. D. (2015). Decision making strategic value based local wisdom Tongkonan North Toraja. Man India, 95(3), 633-639. 
Upe, A., Salman, D., \& Agustang, A. (2019). The effects of the exploitation of natural resources towards risk society construction in Southeast Sulawesi Province, Indonesia. Journal of Degraded and Mining Lands Management, 6(2), 1587.

Awaru, A. O. T., Idris, R., \& Agustang, A. (2018, October). Sexual Education at High School Sinjai East. In 1st International Conference on Social Sciences (ICSS 2018). Atlantis Press.

Idris, M., Ramli, M., Agustang, A., \& Kesuma, A. I. (2015). Bureaucracy Ethics Based in Public Service Local Wisdom in Gowa. Mediterranean Journal of Social Sciences, 6(6 S4), 419-419.

Agustang, A., Pada, A. T., \& Bastiana, M. (2018, October). Social Interaction of Local Communities With Migrants and Changes in The Structure of Local Communities (Study on Plural Society in Makassar Industrial Area). In 1st International Conference on Social Sciences (ICSS 2018). Atlantis Press.

Wardah, S., Salman, D., Agustang, A., \& Fahmid, I. M. (2017). The Contestation of Organic and Non-Organic Agricultural Knowledge in Sustainable Agriculture. Mediterranean Journal of Social Sciences, 8(2), 245-245.

Agustang, A. (2018). SIMBOLIKHAJI: Studi Deskriptif Analitik pada Orang Bugis. Al-Qalam, 15(2), 317-334.

Pannyiwi, R., Agustang, A., Kasnawi, T., Pada, A. T., Yani, A., \& Syam, S. (2020). Social Network for Drug Circulation in Sidenreng Rappang Regency, Indonesia. Systematic Reviews in Pharmacy, 11(9), 575-577.

Agustang, A., \& Soelthan, A. (2015). Analysis of the Inhibiting Factors of Transparency in the Implementation of Local Governance. Mediterranean Journal of Social Sciences, 6(6 S4), 464.

Nain, U., \& Agustang, A. (2020). Analysis On The Utilization Of Village Funds In Cash For Work Program In Bulukumba Regency, South Sulawesi Indonesia. International Journal of Advanced Science and Technology, 29(7s), 2811-2818.

Azis, F., Idris, R., \& Agustang, A. (2017). Involution Fisheries: Post-Study Model of National Program in Integrated Movement at Community Fishermen's Village Development Arungkeke, Jeneponto. Mediterranean Journal of Social Sciences, 8(1), 441.

Agustang, A. D. M. P., \& Nur, H. (2020). Konflik Mahasiswa Parang Tambung Universitas Negeri Makassar. Phinisi Integration Review, 3(1), 46-54.

Rasyid, R., Agustang, A., Maru, R., Agustang, A. T. P., \& Sudjud, S. (2020). PENYULUHAN PENCEGAHAN PENYALAHGUNAAN NARKOBA DI KALANGAN PELAJAR SMP NEGERI 6 DUAMPANUA KABUPATEN PINRANG. JMM (Jurnal Masyarakat Mandiri), 4(2), 116-123.

Rahmania, S., \& Agustang, A. (2017). PRESEPSI MAHASISWA FIK TERHADAP PENYIMPANGAN SEKSUAL LESBIAN (STUDI KASUS PADA MAHASISWA FIK UNM). JURNAL SOSIALISASI, 162-168. 
Ashar, A., \& Agustang, A. (2020). Dampak Sosial Dana Desa Dalam Kesejahteraan Masyarakat Di Desa Kalola, Kecamatan Maniangpajo, Kabupaten Wajo. Jurnal Sosialisasi: Jurnal Hasil Pemikiran, Penelitian dan Pengembangan Keilmuan Sosiologi Pendidikan, (1), 19-25.

Yusuf, M., \& Agustang, A. (2020). DINAMIKA PERUBAHAN SOSIAL EKONOMI PADA MASYARAKAT KINDANG KABUPATEN BULUKUMBA. Jurnal Sosialisasi: Jurnal Hasil Pemikiran, Penelitian dan Pengembangan Keilmuan Sosiologi Pendidikan, (2), 31-37.

Fransina, M., \& Andi, A. (2019). THE ANALYSIS OF EXISTENCE OF MIGRATION IN THE CONTEXT OF BASUDARA COMMUNITY IN AMBON CITY, INDONESIA. Russian Journal of Agricultural and Socio-Economic Sciences, 94(10).

Usman, A., Agustang, A., Djalal, D., \& Annas, S. (2018, October). The Contribution Of Supporter Community In Maximizing Their Role For The Advancement Of Makassar Football Club (PSM). In 1st International Conference on Social Sciences (ICSS 2018). Atlantis Press.

Agustang, A., \& Oruh, S. Factors affecting of heropnam of mental disorders in Dadi Regional Hospital in South Sulawesi Province. Man In India, 97(11), 233-244.

Pratiwi, E. L., \& Agustang, A. (2018). PERSEPSI ORANGTUA SISWA TERHADAP TINDAKAN GURU DALAM MENDISIPLINKAN SISWA DI SMK YPKK LIMBUNG. JURNAL SOSIALISASI, 6-10.

Asri, A., Kasnawi, T., \& Agustang, A. Actors' Social Tensions on Traditional Birth Attendants and Midwife Partnerships in Childbirth Assistance (Sociology of Health Study in Bulukumba Regency).

Bahri, S., Kasnawi, T., Agustang, A., \& Adam, A. (2017). Vegetarian Community Social Movement (Analysis of Health Sociology in Makassar). The Social Sciences, 12(10), 1824-1831.

Djalante, A., Agustang, A., Tahmir, S., \& Sahabuddin, J. A Disadvantaged Tribe in Bajoe Village, Bone Regency: A Phenomenological Research on Bajo Tribe's Social Life in Bone Regency, South Sulawesi.

Rahmawati, R., \& Agustang, A. (2018). PERBANDINGAN POLA ASUH ORANG TUA SISWA BERPRESTASI DENGAN SISWA YANG TIDAK BERPRESTASI DI SMA NEGERI 2 GOWA. JURNAL SOSIALISASI, 115-119.

Agustang, A. (2018). PERAN WALI KELAS DALAM PENYELESAIAN KONFLIK ANTAR SISWA DI SMA NEGERI 1 PINRANG. JURNAL SOSIALISASI, 12-16.

Irnawaty, I., \& Agustang, A. (2019). SMARTPHONE ADDICTION PADA MAHASISWA PENDIDIKAN SOSIOLOGI FAKULTAS ILMU SOSIAL UNIVERSITAS NEGERI MAKASSAR. JURNAL SOSIALISASI, 41-46.

Zainuddin, M., \& Agustang, A. (2019). KONTROL SOSIAL ORANGTUA TERHADAP PENGGUNAAN SMARTPHONE PADA REMAJA (STUDI DI DESA GIRING-GIRING KECAMATAN BONTONMPO KABUPATEN GOWA. JURNAL SOSIALISASI, 68-73. 
Sofyan, Y., \& Agustang, A. (2018). PENERAPAN MODEL PEMBELAJARAN KOOPERATIF TIPE NHT (NUMBERED HEADS TOGETHER) TERHADAP KEAKTIFAN BELAJAR SISWA KELAS XI IPS 1 SMAN 8 MAKASSAR. JURNAL SOSIALISASI, 158-165.

Agustang, A. (2018). PENERAPAN PUNISHMENT DALAM MEMBENTUK $\begin{array}{llllll}\text { KARAKTER DISIPLIN SISWA DI SMA NEGERI } & 1\end{array}$ TAKALAR. JURNAL SOSIALISASI, 126-130.

Amiruddin, T. K., Agustang, A., \& Idris, R. (2014). RELIGIOUS CONVERSION IN MARRIED LIFE IN MAKASSAR, THE CASE OF CHRISTIANITY TO ISLAM. JOURNAL OF ACADEMIC RESEARCH, 6(6), 264.

Machmuddin, H., Agustang, A., Kahar, F., \& Bustan, N. (2015). IMPROVING THE QUALITY OF PRIMARY HEALTH SERVICES IN THE PERSPECTIVE OF PARTICIPATORY GOVERNANCE. International Journal of Academic Research, 7(1).

Agustang, A., \& Sahabuddin, J. (2020, October). MODEL KOLABORASI SOSIAL PENDIDIKAN KARAKTER DI SEKOLAH SWASTA KECAMATAN BISSAPPU KABUPATEN BANTAENG. In PROSIDING SEMINAR DAN DISKUSI PENDIDIKAN DASAR.

Astinah, A., Idris, R., \& Agustang, A. (2020). AGILE LEADERSHIP AND DIVORCE EDUCATION: STUDY ON WOMEN'S PERCEPTION. Humanities, 8(3), 323-330.

Muis, I., Agustang, A., \& Adam, A. (2020). Elderly Poverty: Social Demographic, Work Distribution, Problem Health \& Social Protection. Asian Journal of Social Sciences \& Humanities Vol, 9(1).

Agustang, A. (2020). Symbolic Violence towards Students in the Context of the Existence of the Stereotypical Frames of Lecturers and Students in the Higher Education System in Indonesia. PalArch's Journal of Archaeology of Egypt/Egyptology, 17(2), 249-258.

Asrifan, A. (2009). Using songs in teaching English language for the young learners. ParePare: unpublished.

Puasa, K., Asrifan, A., \& Chen, Y. (2017). Classroom Talk in Bilingual Class Interaction. Research in Pedagogy, 7(1), 106-121.

Nadirah, N., Tahir, M. H., \& Asrifan, A. (2019). THE ABILITY TO TRANSLATE ENGLISH PHRASES INTO INDONESIAN AND THE DIFFICULTIES FACED BY THE ELEVENTH GRADE STUDENTS OF SMAN 1 PANCARIJANG. JOURNAL OF ADVANCED ENGLISH STUDIES, 2(1), 41-46.

Apdy, A. P. R., \& Asrifan, A. (2019, April). The Chinese mime game in teaching vocabulary on EFL classroom. In PROCEEDINGS OF THE 65th TEFLIN INTERNATIONAL CONFERENCE (Vol. 65, No. 01).

Taslim, T., Asrifan, A., Chen, Y., \& Nurdania, N. R. (2019). CORRELATION BETWEEN STUDENT'S VOCABULARY MASTERY AND SPEAKING SKILL. JOURNAL OF ADVANCED ENGLISH STUDIES, 2(2), 65-76.

Muthmainnah, M., Asrifan, A., Al Yakin, A., \& Sahabuddin, C. (2019, April). The use of dictogloss technique on ELT classroom: An experiment study 
of students listening comprehension. In PROCEEDINGS OF THE 65th TEFLIN INTERNATIONAL CONFERENCE (Vol. 65, No. 01).

Mutmainnah, M., Azis, S., Maulidya, U., \& Asrifan, A. (2017). Glory Style in Mandar Song Lyrics: A study of Mandar Tribe in South Sulawesi, Indonesia. JOURNAL OF ADVANCES IN LINGUISTICS, 8(1), 12861291.

Asrifan, A., Rinantanti, Y., Tang, S., \& Nadirah, N. (2019). THE 3-DIMENSION PICTURES IN INCREASING THE STUDENTS ABILITY AND INTEREST TO WRITE DESCRIPTIVE COMPOSITION. JOURNAL OF ADVANCED ENGLISH STUDIES, 2(1), 19-30.

Asrifan, A., Nadira, N., \& Haedar, H. (2018). IMPROVING STUDENTS'READING COMPREHENSION OF DESCRIPTIVE TEXT THROUGH COLLABORATIVE MURDER. JOURNAL OF ADVANCED ENGLISH STUDIES, 1(2), 21-31.

Asrifan, A. (2015). Analysis of English Students' Learning Style in Bilingual Class. International Journal of Literature and Arts, 3(4), 34.

Farahdiba, S., \& Asrifan, A. (2016). Speaking Ability and Psychological Barriers of the Second Year Students of Hotel Department of SMKN 1 Sidenreng Kabupaten Sidrap in Speaking English. Asian EFL Journal, (89), 41.

Asrifan, A. (2012). Increasing the Students Ability to Write Descriptive Composition at SMP Negeri 13 Parepare by using the 3-Dimension Pictures.

Tang, S., Asrifan, A., Chen, Y., Haedar, H., \& Agussalim, M. (2019). THE HUMOR STORY IN TEACHING READING COMPREHENSION. JOURNAL OF ADVANCED ENGLISH STUDIES, 2(2), 77-87.

Nurwanti, N., Asrifan, A., \& Haedar, H. (2019). THE APPLICATION OF COOPERATIVE LEARNING: JIGSAW II TECHNIQUE IN IMPROVING STUDENTS'READING COMPREHENSION OF EXPOSITORY TEXT. JOURNAL OF ADVANCED ENGLISH STUDIES, 2(1), 31-40.

Asrifan, A. (2016). The Effectiveness of Think-Pair-Share Technique in Improving Studentsâ€TM Speaking Ability and Interest. English Literature and Language Review, 2(3), 24-35.

Asrifan, A., Muthmainnah, M., Al-Yakin, A., Sahabuddin, C., \& Haedar, H. (2018). THE CAUSE-EFFECT TECHNIQUE IN TEACHING RECOUNT WRITING. JOURNAL OF ADVANCED ENGLISH STUDIES, 1(2), 63-72.

Asrifan, A., Vargheese, K. J., Syamsu, T., \& Amir, M. (2020). ESP COURSE DESIGN: THE NEED ANALYSIS ON TOURISM DEPARTMENT IN INDONESIA VOCATIONAL HIGH SCHOOLS. JOURNAL OF ADVANCED ENGLISH STUDIES, 3(2), 69-77.

Asrifan, A., Ghofur, A., \& Azizah, N. (2020). Cheating Behavior in EFL Classroom (A Case Study at Elementary School in Sidenreng Rappang Regency). OKARA: Jurnal Bahasa dan Sastra, 14(2), 279-297. 
Nadirah, N., Asrifan, A., Vargheese, K. J., \& Haedar, H. (2020). INTERACTIVE MULTIMEDIA IN EFL CLASSROOM: A STUDY OF TEACHING READING COMPREHENSION AT JUNIOR HIGH SCHOOL IN INDONESIA. JOURNAL OF ADVANCED ENGLISH STUDIES, 3(2), 131-145.

Muthmainnah, A. R., Atmowardoyo, H., Salija, K., \& Asrifan, A. (2020). Literary Work as Teaching Materials: A Study of Students and Lecturers Needs Analysis. Solid State Technology, 63(5), 394-407.

Tilome, A. A., Agustang, A., Jasruddin, M. S., \& Asrifan, A. (2020). Social Exchange of Political Elites in the Regional Leader Election of Gorontalo Province, Indonesia. Solid State Technology, 63(5), 521-531.

Pacinongi, A., \& Asrifan, A. (2020). Bimbingan Pengawas Berkelanjutan dalam Mewujudkan Pendidikan Karakter Bangsa dalam Kegiatan Belajar Mengajar Penjaskes. Celebes Education Review, 2(1), 1-7.

Gunawan, G., \& Asrifan, A. (2020). Penerapan Kerja Kelompok Kegiatan MGMP Guru Ekonomi dalam Menyusun RPP untuk Meningkatkan Kompetensi Pedagogik. Celebes Education Review, 2(1), 31-36.

Yusuf, I., \& Asrifan, A. PENINGKATAN AKTIVITAS KOLABORASI PEMBELAJARAN FISIKA MELALUI PENDEKATAN STEM DENGAN PURWARUPA PADA SISWA KELAS XI IPA SMAN 5 YOGYAKARTA. Editorial Team, 32.

Al Yakin, A., Sahabuddin, C., Rahayu, A., Fitrah, N., \& Arifin, M. (2020). Political Celebrification and Electability: A Study of Political Phenomena Imaging in Election Polewali Mandar District, West Sulawesi, Indonesia. Solid State Technology, 63(5), 632-646.

Junaedah, S. B. T., \& Ahmad, M. A. (2020). The Outdoor Learning Modules Based on Traditional Games in Improving Prosocial Behaviour of Early Childhood. International Education Studies, 13(10).

Octaberlina, L. R., \& Muslimin, A. I. (2020). Efl students perspective towards online learning barriers and alternatives using moodle/google classroom during covid-19 pandemic. International Journal of Higher Education, 9(6), 1-9.

Octaberlina, L. R., \& Anggarini, I. F. (2020). Teaching vocabulary through picture cards in Islamic Elementary School: a case study in Nida Suksa School, Thailand. Jurnal Madrasah, 13(1), 26-38.

Octaberlina, L. R. (2016). Plagiarism in English language theses in Indonesia. Jurnal Ilmu Pendidikan, 14(3).

Octaberlina, L. R., \& Anggarini, I. F. (2020). Teaching vocabulary through picture cards in Islamic Elementary School: a case study in Nida Suksa School, Thailand. Jurnal Madrasah, 13(1), 26-38.

Asrifan, A., Zita, C. T., Vargheese, K. J., Syamsu, T., \& Amir, M. (2020). THE EFFECTS OF CALL (COMPUTER ASSISTED LANGUAGE LEARNING) TOWARD THE STUDENTS'ENGLISH ACHIEVEMENT AND ATTITUDE. JOURNAL OF ADVANCED ENGLISH STUDIES, 3(2), 94-106. 
Asrifan, A. (2021). ACADEMIC WRITING. LawArXiv. January, 2. https://doi.org/10.31228/osf.io/x2s7e

Asrifan, A. (2020). TUTORIAL PENGGUNAAN QUIZIZZ (www. quizizz. com) PADA PEMBELAJARAN. https://doi.org/10.31219/osf.io/kqnza

Asrifan, A. (2021). Abd Ghofur.“. THE USE OF READING CIRCLES IN INCREASING STUDENTS SPEAKING ABILITY AT THE ELEVENTH GRADE SMK https://doi.org/10.31219/osf.io/8vjxy

Asrifan, A. (2020). Pandemic, Humanity and Education. https://doi.org/10.31219/osf.io/q2gpk

Asrifan, A. (2021). USING CAT AND MOUSE GAME TO IMPROVE STUDENT'S SPEAKING ABILITY AT THE ELEVENTH GRADE OF MA YMPI RAPPANG. https://doi.org/10.31219/osf.io/phtvn

Asrifan, A., \& Ghofur, A. (2021). THE USE OF READING CIRCLES IN INCREASING STUDENTS SPEAKING ABILITY AT THE ELEVENTH GRADE SMK NEGERI 1 PANCARIJANG. https://doi.org/10.31219/osf.io/8vjxy

Asrifan, A. (2021). Book Review: Halliday. 1989. Spoken and Written Language. Oxford University Press. https://doi.org/10.31219/osf.io/ej8tb

Asrifan, A., \& Ghofur, A. (2021). TALK, ACTION, SILENCE, INTERRUPTION AND THEIR IMPLICATIONS IN BUGINESE SOCIETY (SOPPENG REGENCY). https://doi.org/10.31219/osf.io/pv3ku

Asrifan, A. (2020). PENILAIAN BERBASIS ANDROID MENGGUNAKAN APLIKASI PLICKERS. https://doi.org/10.31219/osf.io/htreq

Sapulette, A. A., Agustang, A., \& Syukur, M. Actor Construction in the Frame of Diversity to Achieve Social Harmony in the Life of Tamilouw Village Society Seram Island-Maluku.

Amiruddin, T. K., Agustang, A., \& Idris, R. (2014). RELIGIOUS CONVERSION IN MARRIED LIFE IN MAKASSAR, THE CASE OF CHRISTIANITY TO ISLAM. JOURNAL OF ACADEMIC RESEARCH, 6(6), 264.

Machmuddin, H., Agustang, A., Kahar, F., \& Bustan, N. (2015). IMPROVING THE QUALITY OF PRIMARY HEALTH SERVICES IN THE PERSPECTIVE OF PARTICIPATORY GOVERNANCE. International Journal of Academic Research, 7(1).

Agustang, A., \& Sahabuddin, J. (2020, October). MODEL KOLABORASI SOSIAL PENDIDIKAN KARAKTER DI SEKOLAH SWASTA KECAMATAN BISSAPPU KABUPATEN BANTAENG. In PROSIDING SEMINAR DAN DISKUSI PENDIDIKAN DASAR.

Mutiara, I. A., Agustang, A., Adam, A., Upe, A., \& Equatora, M. A. (2020). The dynamics of prostitutes lives in metropolitan cities. Journal of Critical Reviews. https://doi. org/10.31838/jcr, 7, 165.

Haulussy, R. H., Najamuddin, I. R., \& Agustang, A. D. M. P. (2020). The sustainability of the Sasi Lola tradition and customary law (Case study in Masawoy Maluku, Indonesia). Intl J Sci Technol Res, 9(2), 5193-5195. 
Agustang, A. (2020). Symbolic Violence towards Students in the Context of the Existence of the Stereotypical Frames of Lecturers and Students in the Higher Education System in Indonesia. PalArch's Journal of Archaeology of Egypt/Egyptology, 17(2), 249-258.

Agustang, A. (2015). Dasar-Dasar Filsafat Penelitian Untuk Pengembangan Ilmu.

Agustang, A. T. P. Muh. Said, dan Rusman Rasyid. 2015. Perkembangan Peran Jender Dalam Prespektif Teori Androgini, 1-8.

Rasyid, R., Agustang, A., Agustang, A. T. P., Bastiana, B., \& Najamuddin, N. Analisis Faktor Yang Mempengaruhi Status Kemiskinan Rumah Tangga Pada Wilayah Central Bussiness District (CBD) di Kota Makassar. Majalah Geografi Indonesia, 34(1), 43-52.

Asmi, A. S., Kasnawi, M. T., Agustang, A., \& Yani, A. (2020). Sociocultural Transformation in Efforts to Reduce Mortality of Infants in Bone Regency, Indonesia. Systematic Reviews in Pharmacy, 11(10), 762-765.

Agustang, A. (2020, October). Social Actions of Galla Actors in the Kaemba Maros Traditional Village Community Sulawesi Selatan. In 3rd International Conference on Social Sciences (ICSS 2020) (pp. 748-753). Atlantis Press.

Agustang, A. (2020). The Symbolic Violence Towards Private School Students Through The Frame Stereotype In Bantaeng District Of Indonesia. Prosiding ICoISSE, 1(1), 578-588.

Ariani $^{1}$, A. I., Agustang, A., Adam, A., \& Alimsyah, S. (2020). INSTITUTIONAL FAILURES IN THE WORLD OF EDUCATION IN SCHOOLS FOR CHILDREN VICTIMS OF PARENTS. Asian Journal of Social Sciences \& Humanities Vol, 9, 2. 